\title{
Biocompatibility of Apatite-coated Titanium Mesh Prepared by Hydrothermal- electrochemical Method
}

\author{
Akihiko YUDA ${ }^{1}$, Seiji BAN ${ }^{2}$ and Yuichi IZUMI ${ }^{1}$ \\ ${ }^{1}$ Department of Periodontology, Kagoshima University Graduate School of Medical and Dental Sciences, 8-35-1, Sakuragaoka, \\ Kagoshima 890-8544, Japan \\ ${ }^{2}$ Department of Biomaterials Science, Kagoshima University Graduate School of Medical and Dental Sciences, 8-35-1, \\ Sakuragaoka, Kagoshima 890-8544, Japan \\ Corresponding author, Akihiko Yuda E-mail:a-yuda@denta.hal.kagoshima-u.ac.jp
}

Received June 29, 2005/Accepted September 28, 2005

\begin{abstract}
The hydrothermal-electrochemical method is best suited for producing homogeneous apatite coatings on electro-conductive materials with complicated shape, such as the mesh. This study was undertaken to examine the effect of the apatite coating prepared by this coating method on cell adhesion, proliferation, and differentiation of MC3T3-E1 cells in culture. The cells attached and spread well on the electrochemically deposited apatite on titanium mesh. The number of cells that adhered on the deposited apatite on titanium mesh was much greater than that on the surface without coating, and that it also depended on the morphology of apatites. When alkaline phosphatase activity as well as collagen and osteocalcin of the extracellular matrix were measured, the electrochemically apatite-coated titanium mesh showed higher measurement values than the titanium mesh without coating. These results suggested that the apatite-coated titanium mesh prepared by hydrothermal-electrochemical method has excellent biocompatibility.
\end{abstract}

Key words: Apatite, Biocompatibility, Biomaterials

\section{INTRODUCTION}

Polymers or copolymer acids, calcium phosphates, and collagen have been employed as scaffold materials, which are a creative development of osteoinductive bone graft substitutes. A disadvantage of these materials is that they are not very strong and can transform easily ${ }^{1)}$. Titanium mesh has been used in plastic surgery and oral surgery, because it has excellent mechanical properties in terms of stiffness and elasticity, bone compatibility, and ease of use during surgery ${ }^{2)}$. For example, the use of titanium mesh was rekindled by von Arx et al. in the TIME technique, whereby microtitanium augmentation mesh was specifically designed for ridge augmentation $^{3)}$.

An additional advantage of titanium is that it can be used as a substrate for calcium phosphate coating - which has been described to have a positive effect on bone formation. It is generally assumed that calcium phosphate coatings enhance bone formation. In fact, Vehof et $a l^{4)}$ showed that calcium phosphate-coated titanium mesh facilitated excellent bone generation, whereby this coating was prepared by magnetron sputtering.

In terms of coating method, a number of coating techniques are available: plasma spray ${ }^{5,6)}$, ion-beamassisted deposition ${ }^{7)}$, and radiofrequency magnetron sputtering ${ }^{8)}$. However, regarding the long-term performance of coatings obtained via these methods, some drawbacks have been noticed: poor mechanical properties and non-homogeneity ${ }^{9)}$. We have been studying apatite coating on titanium by hydrothermal-electrochemical deposition ${ }^{10-18)}$. The advantages of this coating method are that it easily produces a homogeneous apatite coating on electroconductive materials with complicated shape such as mesh $^{19,20)}$, requires a lower processing temperature, and entails only simple and inexpensive preparation method. Further, it is known that apatite coatings can promote bone ingrowths, enhance direct bone contact $^{21)}$, as well as facilitate differentiation of bone marrow stromal cells along the osteogenic lineage ${ }^{22)}$.

The purpose of the present study was to investigate the effect of electrochemically deposited apatite on cell adhesion, proliferation, and differentiation of MC3T3-E1 cells in culture, and thereby to discuss the biocompatibility of titanium mesh with apatite coating.

\section{MATERIALS AND METHODS}

\section{Sample preparation}

Grid 80 mesh woven with $120-\mu \mathrm{m}$ diameter titanium fibers (458080, Nilaco, Tokyo, Japan) was cut to 10 $\times 10 \mathrm{~mm}$ squares. Surface area of the $10-\mathrm{mm}$ square titanium mesh was derived from the dimensional parameters of the mesh. Apatites were formed on this titanium mesh using a hydrothermal-electrochemical method. The electrolyte was prepared by dissolving $137.8 \mathrm{mM}$ of $\mathrm{NaCl}, 1.67 \mathrm{mM}$ of $\mathrm{K}_{2} \mathrm{HPO}_{4}$, and $2.5 \mathrm{mM}$ of $\mathrm{CaCl}_{2} \cdot 2 \mathrm{H}_{2} \mathrm{O}$ in distilled water. The solution was buffered to $\mathrm{pH} 7.2$ at room temperature with $50 \mathrm{mM}$ tris (hydroxymethyl)-aminomethane $\left[\left(\mathrm{CH}_{2} \mathrm{OH}\right)_{3} \mathrm{CNH}_{2}\right]$ 
and an adequate amount of $\mathrm{HCl}$. The autoclave contained $1 \mathrm{~L}$ of the electrolyte in a Pyrex beaker and was sealed by bolting under a Teflon gasket. The electrolyte was then heated and maintained at 90, 100 , and $150^{\circ} \mathrm{C}$ in a stainless steel autoclave with two electrodes. Anode, the counter electrode, was a $20 \times$ $20 \times 0.5 \mathrm{~mm}$ platinum plate. A constant direct current was loaded at $12 \mathrm{~mA} / \mathrm{cm}^{2}$ to the \#80 titanium meshes for one hour. After constant current loading, the titanium mesh as cathode was rinsed with distilled water and dried at $37^{\circ} \mathrm{C}$. More details about the hydrothermal-electrochemical deposition of apatite were discussed in our previous papers ${ }^{12,20)}$.

The deposits were then characterized by scanning electron microscopy (SEM; JSM-5510, JEOL, Tokyo, Japan), X-ray diffractometry (XRD; RINT 2500, Rigaku, Tokyo, Japan), and energy dispersive X-ray spectrometry (EDS; JED-2200, JEOL, Tokyo, Japan).

\section{Cell cultures}

Mouse osteoblast-like cells (MC3T3-E1) were cultured at $37^{\circ} \mathrm{C}$ in a humidified atmosphere of $5 \% \mathrm{CO}_{2}$ in air. The cell suspension was cultured in minimum essential medium alpha modification ( $\alpha$-MEM; Invitrogen, Groningen, Netherlands) with $10 \%$ fetal bovine serum (FBS; Moregate Biotech, Bulimba, Australia) supplemented with $2 \mathrm{mM}$ L-glutamine, $70 \mu \mathrm{g} / \mathrm{ml}$ of benzyl penicillin potassium, and $100 \mu \mathrm{g} / \mathrm{ml}$ of streptomycin sulfate. To induce spontaneous differentiation, $10 \mathrm{mM} \beta$-glycerophosphate as well as $50 \mu \mathrm{g} / \mathrm{ml}$ ascorbic acid were added to the culture medium. To evaluate the effect of apatite coating on cell attachment in each condition, $1 \times 10^{4} \mathrm{cell} / \mathrm{cm}^{2}$ was plated onto the deposited apatite on the titanium mesh $(0.5$ $\times 0.5 \mathrm{~cm})$ which had been placed into individual wells of a 24-well plate. Cells with the same density were also cultured on a 24 -well plate, which was used as the control group.

\section{Cell attachment and proliferation}

Cells grown on the apatite coating on titanium mesh after three days were fixed in $2.5 \%$ glutaraldehyde with $0.1 \mathrm{M}$ sodium cacodylate buffer ( $\mathrm{pH} 7.4$ and 4 ${ }^{\circ} \mathrm{C}$ ) for one hour and postfixed for 30 minutes with $1 \%$ osmium tetroxide in $0.1 \mathrm{M}$ cacodylate buffer. After dehydration in graded ethanols, specimens were transferred into t-butyl alcohol and freeze-dried. Specimens were sputter-coated with gold, and cell morphology was observed by SEM.

Cell proliferation was measured at 4, 8, and 12 days. Cells in each well were counted using a kit (Cell-counting Kit-8, Dojindo Laboratories, Kumamoto, Japan). The counting technique employed a tetrazolium salt that produced a highly water-soluble formazan dye. After one hour of incubation with reagent according to the manufacturer's instructions, relative cell number was determined by measuring light absorbance at a wavelength of 450 $\mathrm{nm}$ by formazan dye product in the cultures.

\section{Alkaline phosphatase $(A L P)$ activity}

For quantitative analysis of ALP activity, cells were washed twice with phosphate-buffered saline (PBS; Nissui Pharmaceutical, Tokyo, Japan) and sonicated for 10 seconds with lysis buffer $(1.5 \mathrm{M}$ Tris- $\mathrm{HCl}$ at $\mathrm{pH} 9.2,1 \mathrm{mM} \mathrm{ZnCl}, 1 \mathrm{mM} \mathrm{MgCl}_{2} \cdot 6 \mathrm{H}_{2} \mathrm{O}$, and $1 \%$ Triton $\mathrm{X}-100)$. ALP activity in this lysate was measured at $37^{\circ} \mathrm{C}$ for 15 minutes in $7.5 \mathrm{mM}$ alkaline buffer solution (Sigma 221, Sigma, St. Louis, MO, USA) with $p$-nitrophenol phosphate (Sigma 104) as a substrate. The relative amount of $p$-nitrophenol was estimated by measuring light absorbance at a wavelength of $405 \mathrm{~nm}$. Known dilutions of $p$-nitrophenol solution (Sigma 104-1) were used as a standard. ALP activity was expressed relative to protein content of samples as determined using a DC protein assay kit (Bio-Rad Laboratories, Hercules, CA, USA).

\section{Collagen assay}

Collagen was determined by a soluble collagen assay kit (Biodye Science, Northern Ireland). Standards (soluble type I collagen), test samples, and blanks were added into microcentrifuge tubes, followed by 1 $\mathrm{ml}$ dye reagent. All the tubes were capped and placed in a mechanical shaker for 30 minutes. Next, the tubes were transferred to a microcentrifuge and spun at $10,000 \times \mathrm{g}$ for 10 minutes. Unbound dye solution was removed by carefully inverting and draining the tubes, and then $1 \mathrm{ml}$ of an alkaline reagent was added. Aliquots of each sample were transferred from the tubes to the wells of a 96 -well plate. Optical density of each well was determined using a microplate reader set to $540 \mathrm{~nm}$. Sample values were determined by comparison with a standard curve.

\section{Osteocalcin assay}

Osteocalcin was determined by mouse osteocalcin EIA KIT (Biomedical Technologies Inc., MA, USA) according to the manufacturer's instructions. Standards, test samples, and blanks were added to individual wells, followed by biotinylated antibody, and incubated at $4{ }^{\circ} \mathrm{C}$ for 24 hours. After washing, peroxidase conjugate was added to each well and incubated in the dark at room temperature. Light absorbance was measured at $450 \mathrm{~nm}$ wavelength.

\section{Statistical analysis}

For statistical analysis, one-way ANOVA and posthoc Fisher's PLSD test were performed.

\section{RESULTS}

\section{Apatite structure}

After hydrothermal-electrochemical coating, the mesh was homogeneously covered with white deposits (Fig. 
1). SEM photographs showed that the deposits were homogeneously formed on the surface of the titanium fibers (Fig. 2). Plate-like deposits were formed on the titanium mesh at $90^{\circ} \mathrm{C}$. Needle-like and platelike deposits were formed at $100^{\circ} \mathrm{C}$, whereas only needle-like deposits were formed at $150^{\circ} \mathrm{C}$. Thickness of the thin plates at $90{ }^{\circ} \mathrm{C}$ was about $0.1 \mu \mathrm{m}$ and the width was $30-80 \mu \mathrm{m}$. At $100^{\circ} \mathrm{C}$, the needle-like deposits were $0.5-1 \mu \mathrm{m}$ in width and about $7 \mu \mathrm{m}$ in length. At $150{ }^{\circ} \mathrm{C}$, the needle-like deposits were $2-7 \mu \mathrm{m}$ in width and $60-90 \mu \mathrm{m}$ in length. Size of the needle-like deposits increased with the electrolyte temperature. Furthermore, most of the needles grew perpendicular to the surface of the mesh fiber, and their sharp edges were hexagonal.

XRD patterns showed the diffraction peaks due to titanium substrate and apatite in each condition (Fig. 3). It was also found that the diffraction peak corresponding to (002) of the apatite of the deposits

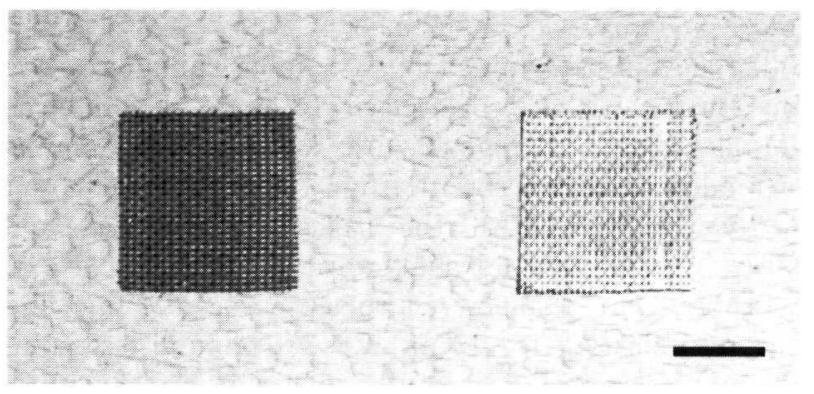

Fig. 1 Photographs of the titanium mesh before (left) and after (right) hydrothermal-electrochemical apatite coating. Scale bar $=5 \mathrm{~mm}$.

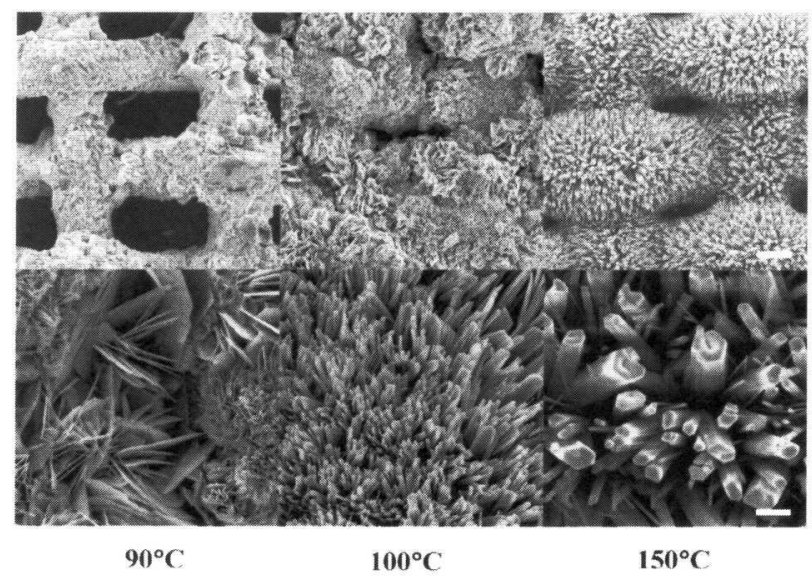

Fig. 2 SEM micrographs of the titanium mesh after hydrothermal-electrochemical apatite coating at 90 , 100 , and $150^{\circ} \mathrm{C}$. Lower photos were high magnification of the center area of the upper ones. Scale bar $=100 \mu \mathrm{m}$ (upper), $10 \mu \mathrm{m}$ (lower). had a higher intensity in comparison to the standard intensity, indicating an orientation to the $c$-axis direction of the apatite crystal. Therefore, it can be concluded that the needle-like crystal was a hydroxyapatite single crystal with $<001\rangle$ preferred orientation, indicating growth parallel to the $c$-axis direction.

$\mathrm{Ca} / \mathrm{P}$ ratio of the deposits increased with the electrolyte temperature during deposition (Fig.4). $\mathrm{Ca} / \mathrm{P}$ ratios of the deposits at $90^{\circ} \mathrm{C}, 100^{\circ} \mathrm{C}$, and 150 ${ }^{\circ} \mathrm{C}$ were $1.38,1.4$, and 1.54 respectively, indicating a composition of Ca-deficient apatite. This is in agreement with a previous report ${ }^{12)}$ on the $\mathrm{Ca} / \mathrm{P}$ ratios of deposits on titanium plates.

\section{Cell morphology}

SEM observation showed that the morphology of cells attached on the apatite was flattened with numerous cytoplasmic extensions (Fig. 5). On the de-

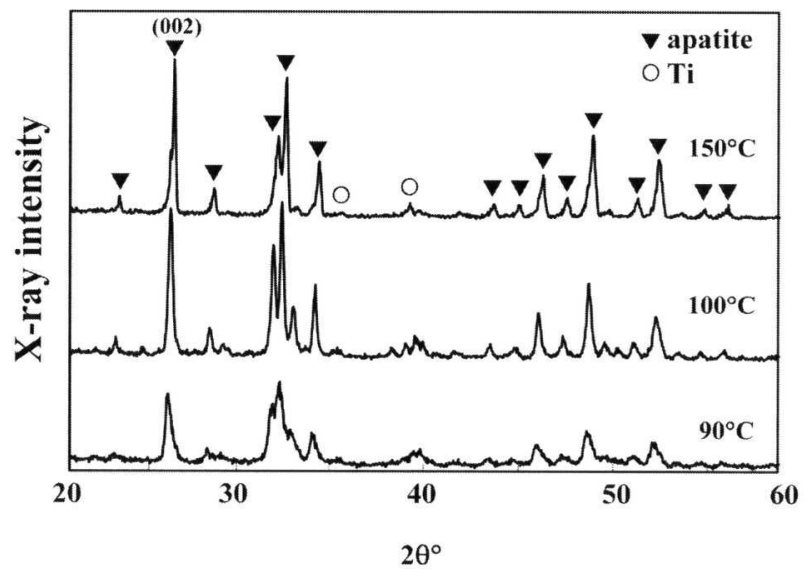

Fig. 3 XRD patterns of the deposits formed after 1 hour under $12 \mathrm{~mA} / \mathrm{cm}^{2}$ at 90,100 , and $150^{\circ} \mathrm{C}$.

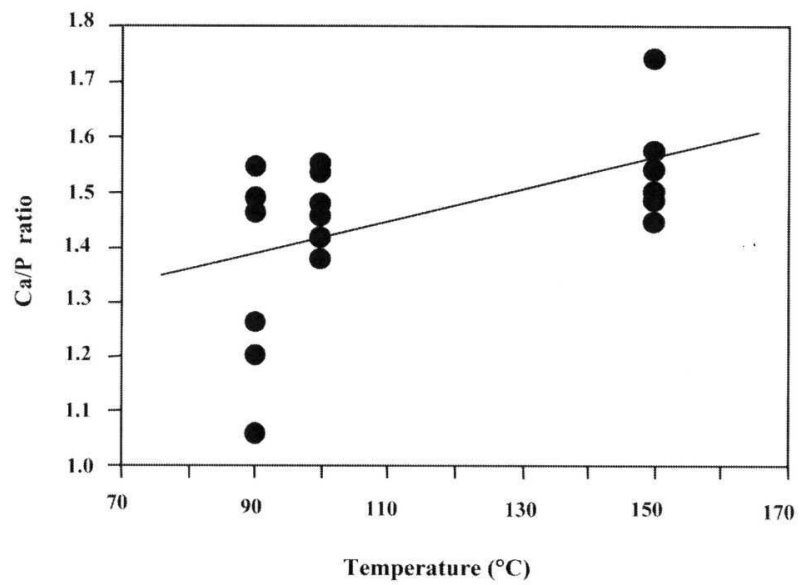

Fig. 4 Relation between $\mathrm{Ca} / \mathrm{P}$ ratio of deposit and the electrolyte temperature. 


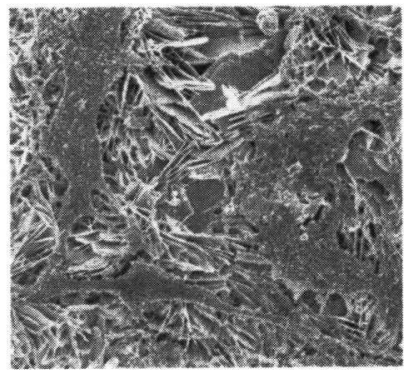

$90^{\circ} \mathrm{C}$

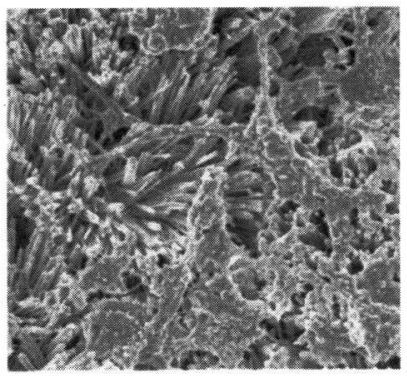

$100^{\circ} \mathrm{C}$

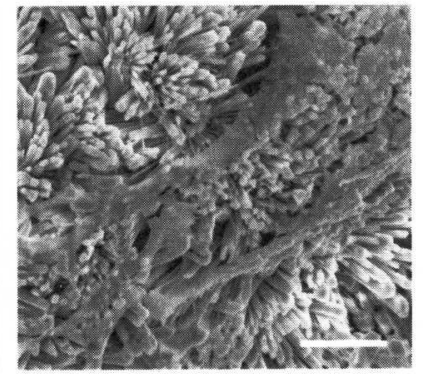

$150^{\circ} \mathrm{C}$

Fig. 5 SEM micrographs of the cell attached to the deposited apatite coating on titanium mesh. Scale bar $=10 \mu \mathrm{m}$.

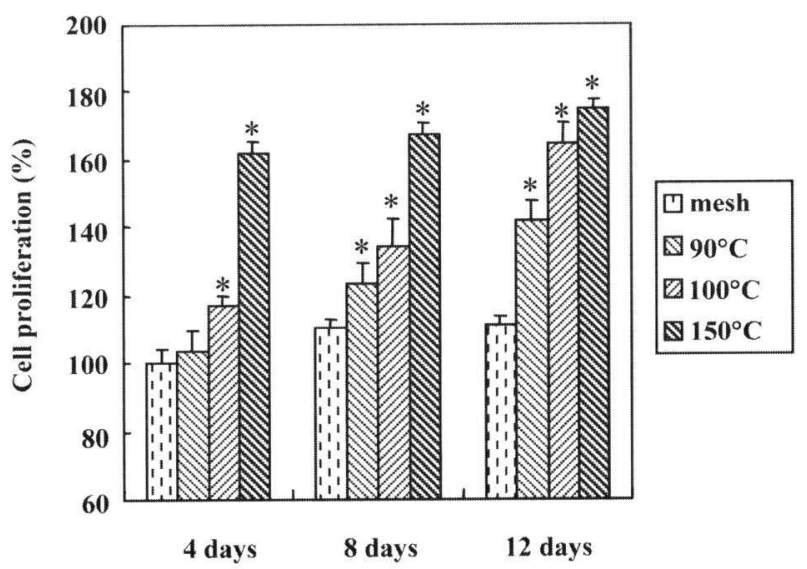

Fig. 6 Proliferation of osteoblast-like cells on the apatitecoated titanium mesh at 4, 8, and 12 days. Error bars indicate the standard deviation of the mean of measurements in six wells.

* Significantly different from mesh $(\mathrm{p}<0.05)$.

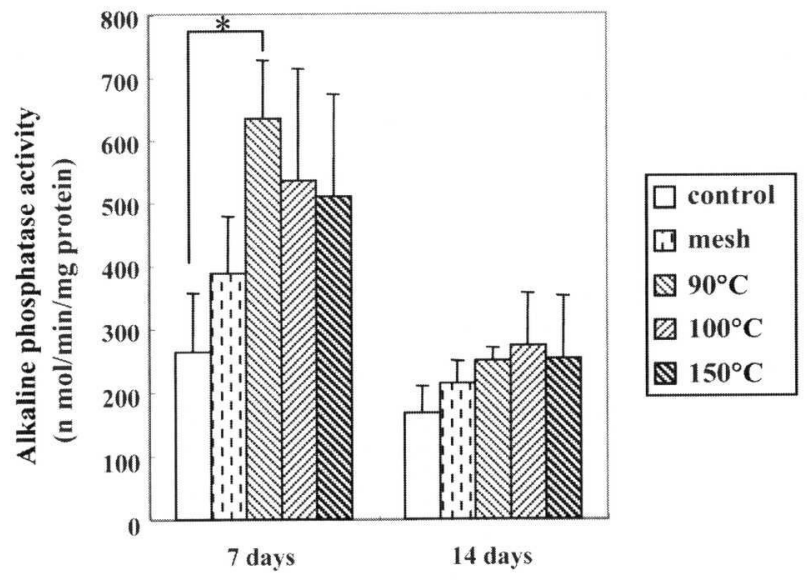

Fig. 7 ALP activity of cultured osteoblast-like cells at 7 and 14 days. Error bars indicate the standard deviation of the mean of measurements in four wells.

${ }^{*}$ Significantly different from control $(p<0.05)$. posited apatite at $150{ }^{\circ} \mathrm{C}$, cells were elongated with narrow cell projections.

\section{Proliferation}

Fig. 6 shows the absorbance directly corresponding to the number of osteoblast-like cells on the apatitecoated titanium mesh and without coating at 4, 8, and 12 days. For titanium mesh without coating, cell proliferation was displayed as $100 \%$ at 4 days. All substrates supported continuous cellular growth at 12 days. The number of adherent cells on the deposited apatite on titanium mesh was much greater than that on the surface without coating, and that it also depended on the morphology of apatites. At all time periods, cells proliferated actively and abundantly on the deposited apatite in the order of 150 ${ }^{\circ} \mathrm{C}, 100^{\circ} \mathrm{C}, 90^{\circ} \mathrm{C}$, and the titanium mesh without coating.

\section{Differentiation}

Fig. 7 shows the ALP activity of cultured osteoblastlike cells at 7 and 14 days. As for the apatite-coated titanium mesh at $90^{\circ} \mathrm{C}$, it was significantly greater $(p<0.05)$ than the control at 7 days. No differences in ALP activity were observed among the three types of deposited apatite specimens.

Fig. 8 shows the amount of collagen produced by cultured osteoblast-like cells on each specimen at 3, 9, and 15 days. Collagen production for all specimens decreased with incubation time. The apatite-coated mesh at $90^{\circ} \mathrm{C}$ and $100{ }^{\circ} \mathrm{C}$ were significantly higher $(\mathrm{p}<0.05)$ than the control and the titanium mesh without coating at 3 days. No differences were observed in the collagen assay at 9 and 15 days.

Fig. 9 shows the osteocalcin assay of cultured osteoblast-like cells at 3,9 , and 15 days. The amounts of osteocalcin on all specimens increased with incubation time. The apatite-coated titanium mesh at $90{ }^{\circ} \mathrm{C}$ and $100{ }^{\circ} \mathrm{C}$ were significantly higher $(\mathrm{p}<0.05)$ than the control and the titanium mesh without coating at 15 days. 


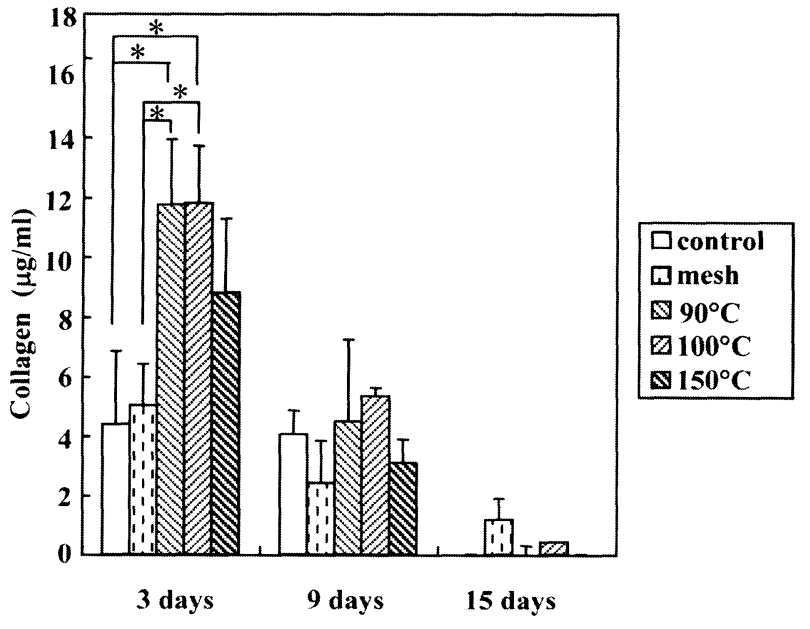

Fig. 8 Collagen produced by cultured osteoblast-like cells on each specimen at 3, 9, and 15 days. Error bars indicate the standard deviation of the mean of measurements in four wells.

* Significantly different from control or mesh $(\mathrm{p}<0.05)$.

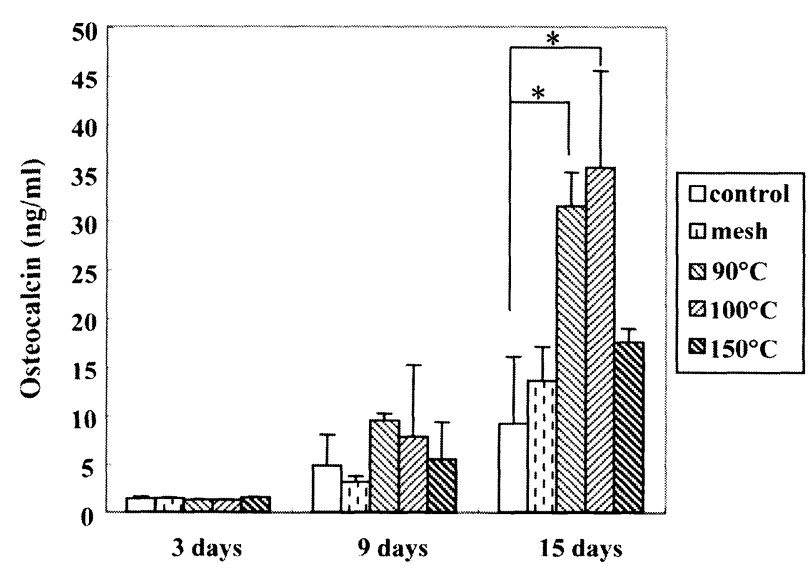

Fig. 9 Osteocalcin assay of cultured osteoblast-like cells at 3, 9, and 15 days. Error bars indicate the standard deviation of the mean of measurements in four wells.

${ }^{*}$ Significantly different from control $(p<0.05)$.

\section{DISCUSSION}

The results in the present study confirmed that apatites were homogeneously formed and oriented on the surface of the titanium mesh using hydrothermal-electrochemical method. Like the coating on a plate ${ }^{14)}$, it was shown in this study that the morphology and dimensions of the deposited apatite could be easily regulated by the electrolytic condition.

Cell culture test in the present study demonstrated that osteoblast-like cells attached well to the electrochemically deposited apatite, and that their morphology affected proliferation. For a barrier membrane (Guided Bone Regeneration), cell attachment to the material is essential because cell replication begins only after the cell has absorbed glycoproteins, established cell-substrate contact, and then adhered to and spread on the substrate ${ }^{23)}$. To allow these cellular events to occur, material used should have no deleterious effects on cell function. Furthermore, the material should possess the capacity to encourage cell spreading and proliferation. A key regulator of proliferation rate in anchoragedependent cells is cell shape ${ }^{24,25)}$. Cells flattened with well-spread configuration divide at a higher rate than those which are rounded ${ }^{24,25)}$. SEM observation in the present study revealed that the attached cell on the electrochemically deposited apatite was flattened with numerous cytoplasmic extensions, and that no detrimental effects on cell development were observed.

Previous studies demonstrated that many factors govern the attachment of osteoblasts ${ }^{27,28)}$. One is the composition and surface topology of the substrate. Deligianni et al. reported that cell attachment was dependent on the surface roughness of hydroxyapatite ${ }^{27)}$. They found that the number of adherent cells per unit surface of apatite increased with the increase of surface roughness. In the present study, a greater number of cells adhered on the electrochemically deposited apatite on titanium mesh than on the surface without coating, as shown in Fig. 6. It seemed like cell adhesion was influenced by surface roughness - a result of deposited apatite on titanium mesh, as compared to the titanium mesh without coating. Indeed, this observation is augmented by a recent report ${ }^{28)}$ that cells adhered more favorably to a sintered hydroxyapatite than to titanium due to a greater adsorption of adhesive ligands and integrins to the hydroxyapatite surface. Therefore, it can be concluded that the electrochemically apatite-coated titanium mesh provided for better cell adhesion. Wang et al. reported that owing to higher dissolution rate and relative rougher surface, carbonate apatite coating demonstrated the best goat bone marrow stromal cells attachment at 1 day and 3 days ${ }^{29)}$. In the present study, the number of adherent cells on the electrochemically apatite-coated titanium mesh at $150^{\circ} \mathrm{C}$ was much higher than on the other samples, although it exhibited a lower dissolution rate. This seemed to be caused by the wider surface area of (100) and (010) planes, which have relatively high dissolution. Furthermore, the difference in cell adhesion to biomaterials is known to depend on the composition or surface physicochemical properties ${ }^{30,31)}$. On this note, the difference in cell attachment according to the form and characteristics of apatite requires further research.

The remarkable result in this study was the higher cellular differentiation on the electrochemically apatite-coated titanium mesh than in the well 
plate. It is well known that apatite enhances osteoblastic differentiation in vitro ${ }^{26,28,32)}$. Ozawa and Kasugai reported that ALP activity and the number of mineralized nodules on apatite produced by rat bone marrow stromal cells were higher than those on a culture plate or titanium ${ }^{32)}$. In addition, Hott et al. demonstrated that collagen synthesis and calcium uptake by human trabecular osteoblastic cells were higher on HAP than on plastic ${ }^{33)}$. With respect to cellular differentiation on apatite-coated titanium mesh versus that in cell culture plastic wells, our results obtained in this study were consistent with their results. The effect of surface roughness and composition of the substrate on osteoblastic differentiation has been studied extensively ${ }^{27,34,35)}$. With respect to surface roughness, it was reported that increased surface roughness resulted in enhanced osteoblastic differentiation and production of matrix proteins, such as type I collagen and osteocalcin, when polystyrene and titanium were employed ${ }^{34,35)}$. In the present study, the electrochemically apatitecoated titanium mesh indicated higher measurement values than the titanium mesh without coating and that of the control in the early stage of the measurement of ALP activity and collagen of the extracellular matrix.

It is also known that the crystallinity degree of apatite influences osteoblastic differentiation ${ }^{36,37)}$. Morgan et $a l .^{36)}$ reported that a significant inverse relationship was found for biologically mediated mineralization as a function of apatite crystallinity: low-crystalline surface had the highest level of mineralization, whereas high-crystalline surface yielded the lowest. Maxian et $a l^{37)}$ reported that gene expressions for osteonectin, osteopontin, and ALP were enhanced by apatite with low crystallinity compared with high crystallinity in rat calvarial bone cell culture system. However, in this study, there were no significant differences in ALP activity among the three types of apatite specimens as shown in Fig. 7. Morgan et al. ${ }^{36)}$ examined ALP activity at 72 hours, Maxian et al. ${ }^{37)}$ did so at 2 days, while we examined ALP activity at 7 and 14 days in this study. It can therefore be concluded that there were significant differences in ALP activity between highcrystalline and low-crystalline surfaces in the early stages of proliferation.

These results demonstrated that the electrochemically apatite-coated titanium mesh showed good cell attachment and proliferation, and had a higher ability to enhance the differentiation of osteoblast-like cells than the titanium mesh without apatite coating. Furthermore, high-crystalline apatite such as the deposited apatite at $150^{\circ} \mathrm{C}$ showed good cell attachment compared with the low-crystalline one, but highcrystalline apatite showed low differentiation when compared with the low-crystalline one. Ban et al. have reported on the pull-out bonding strength between rabbit femora and the titanium bars with and without the electrochemically deposited apatite coating at 100,150 , and $200^{\circ} \mathrm{C}$ after three-week implantation $^{38)}$. The pull-out bonding strength at 100 ${ }^{\circ} \mathrm{C}$ was the highest. This viewpoint may also relate to the higher biocompatibility of the electrochemically deposited apatite at $100^{\circ} \mathrm{C}$ exhibited in this study, but further research is necessary in vivo.

Materials that are used for bone regeneration must provide good mechanical and digestive properties. However, it is very difficult to include these two different characteristics in one material. Sintered ceramics or metal materials have good mechanical strength and are useful for the reconstruction of bone $\mathrm{e}^{39)}$, but they are not resorbed in the body. Some synthesized polymers or bipolymers have bioabsorbability but do not have sufficient strength $^{40-42)}$. For these reasons, more than two materials of different characteristics have to be used to achieve ideal bone regeneration. The electrochemically apatite-coated titanium mesh developed in this study has two different characteristics, due to the differing properties rendered by apatite and titanium mesh.

These results suggested that the apatite-coated titanium mesh prepared by the hydrothermalelectrochemical method has an excellent biocompatibility and it may be clinically applicable to guided bone regeneration.

\section{CONCLUSION}

With hydrothermal-electrochemical deposition method, apatites were homogeneously formed and oriented on the surface of titanium mesh. The cells attached and spread well on the deposited apatite on titanium mesh, whereby the number of adherent cells yielded was much greater than that on the surface without coating.

After measuring alkaline phosphatase activity as well as collagen and osteocalcin of the extracellular matrix, the electrochemically apatite-coated titanium mesh indicated higher measurement values than the titanium mesh without coating. These results suggested that the electrochemically apatite-coated titanium mesh has an excellent biocompatibility.

\section{REFERENCES}

1) Vehof JWM, Mahmood J. Ectopic bone formation in titanium mesh loaded with bone morphogenetic protein and coated with calcium phosphate. Plast Reconst Surg 2001; 108: 434-443.

2) Jansen JA, von Recum AF, van der Waerden, de Grootk. Soft tissue response to different types of sintered metal fiber-web materials. Biomaterials 1992; 13 : 959-968.

3) von Arx T, Hardt N, Wallkam B. The TIME tech- 
nique: A new method for localized alveolar ridge augmentation prior to placement of dental implants. Int $\mathrm{J}$ Oral Maxillofac Implants 1996; 11: 387-394.

4) Vehof JWM, Spauwen PHM, Jansen JA. Bone formation in calcium-phosphate-coated titanium mesh. Biomaterials 2000; 21: 2003-2009.

5) De Groot K, Geesink R, Klein CPAT, Serekian P. Plasma sprayed coatings of hydroxylapatite. J Biomed Mater Res 1987; 21: 1375-1381.

6) Mimura K, Watanabe K, Okawa S, Kobayashi M, Miyakawa O. Morphological and chemical characterizations of the interface of a hydroxyapatite-coated implant. Dent Mater J 2004; 23: 353-360.

7) Cui FZ, Luo ZS, Feng QL. Highly adhesive hydroxyapatite coating on titanium alloy formed by ion beam assisted deposition. J Mater Sci Mater Med 1997; 8: 403-405.

8) Hulshoff JEG, van Dijk K, van der Waerden JPCM, Wolke JGC. Biological evaluation of the effect of magnetron sputtered $\mathrm{Ca} / \mathrm{P}$ coating on osteoblast-like cells in vitro. J Biomed Mater Res 1995; 29: 967-975.

9) Kangasniemi IMO, Verheyen CCPM, van der Velde $\mathrm{EA}$, de Groot K. In vivo tensile testing of fluorapatite and hydroxylapatite plasmasprayed coating. J Biomed Mater Res 1994; 28: 563-572.

10) Ban S, Maruno S. Deposition of calcium phosphate on titanium by electrochemical process in simulated body fluid. Jpn J Appl Phys 1993; 32: 1577-1580

11) Ban S, Maruno S. Effect of temperature on electrochemical deposition of calcium phosphate coatings in a simulated body fluid. Biomaterials 1995; 16: 977-981.

12) Ban S, Maruno S. Hydrothermal-electrochemical deposition of hydroxyapatite. J Biomed Mater Res 1998; 42: 387-395.

13) Ban S, Maruno S. Morphology and microstructure of electrochemically deposited calcium phosphates in a modified simulated body fluid. Biomaterials 1998; 19: 1245-1253.

14) Ban S, Maruno S. Morphological regulation and crystal growth of: hydrothermal-electrochemically deposited apatite. Biomaterials 2002; 23: 2965-2972.

15) Ban S, Matsuno K, Mizutani N, Hasegawa J. Hydrothermal-electrochemical deposition of calcium phosphates on various metals. Dent Mater J 1999; 18: 259-270.

16) Ban S, Hasegawa J. Modification of electrochemically deposited apatite using supercritical water. Dent Mater J 2001; 20: 247-256.

17) Ban S, Kamiya A, Sonoda T. Calcium-ion incorporation into titanium surfaces accompanied by electrochemical apatite-deposition. Dent Mater J 2002; 21: 306313.

18) Ban S. Real-time monitoring of apatite deposition using electrochemical quartz crystal microbalance. Dent Mater J 2003; 22: 467-474.

19) Ban S, Yuda A, Izumi Y. Composite mesh consisting of titanium, apatite and biodegradable copolymer. Key Engin Mater 2004; 254-256: 517-520.

20) Ban S, Yuda A, Izumi Y. Hydrothermalelectrochemical apatite coating on titanium mesh. J
Ceram Soc Japan 2004; 112: 860-862.

21) Yan WO, Nakamura $T$, Kwanabe K, Nishigochi S, Oka M, Kokubo T. Apatite layer-coated titanium for use as bone bonding implants. Biomaterias 1997; 18: 11851190.

22) Ohgushi H, Caplan AI. Stem cell technology and bioceramics: From cell to gene engineering. J Biomed Mater Res 1999; 48: 913-927.

23) Grinnell F. Cellular adhesiveness and extracellular substrata. Int Rev Cytol 1978; 53: 65-144.

24) Folkman J, Moscona A. Role of cell shape in growth control. Nature 1978; 273: 345-349.

25) Archer CW, Rooney P, Wolpert L. Cell shape and cartilage differentiation of early chick limb bud cells in culture. Cell Differentiation 1982; 11: 245-251.

26) Puleo DA, Holleran LA, Doremus RH, Bizios R. Osteoblast responses to orthopedic implant materials in vitro. J Biomed Mater Res 1991; 25: 711-723.

27) Deligianni DD, Katsala ND, Koutsoukos PG, Missirlis YF. Effect of surface roughness of hydroxyapatite on human bone marrow cell adhesion. Biomaterials 2001; 22: $87-96$.

28) Kilpadi KL, Change PL, Bellis SL. Hydroxylapatite binds more serum proteins, purified integrins, and osteoblast precursor cells than titanium or steel. $\mathrm{J}$ Biomed Mater Res 2001; 57: 258-267.

29) Wang J, Layrolle $P$, Stigter M, de Groot K. Biomimetic and electrolytic calcium phosphate coatings on titanium alloy: Physicochemical characteristics and cell attachment. Biomaterials 2004; 25: 583-592.

30) Okumura A, Goto M, Goto T, Yoshinari M, Masuko S, Katsuki T, Tanaka T. Substrate affects the initial attachment and subsequent behavior of human osteoblastic cells (Saos-2). Biomaterials 2001; 222: 22632271.

31) Ohgaki M, Kizuki T, Ktsura M, Yamashita K. Manipulation of selective cell adhesion and growth by surface changes of electrically polarized hydroxyapatite. J Biomed Mater Res 2001; 57: 366-373.

32) Ozawa S, Kasugai S. Evaluation of implant materials (hydroxyapatite, glass-ceramics, titanium) in rat bone marrow stromal cell culture. Biomaterials 1996; 17: 2329.

33) Hott M, Noel B, Bernache-Assolant D, Rey C, Marie PJ. Proliferation and differentiation of human trabecular osteoblastic cells on hydroxyapatite. J Biomed Mater Res 1997; 37: 508-518.

34) Hatano $K$, Inoue $H$, Kojo $T$, Matsunaga $T$, Tsujisawa $\mathrm{T}$, Uchiyama C, Uchida Y. Effect of surface roughness on proliferation and alkaline phosphatase expression of rat calvarial cells cultured on polystyrene. Bone 1999; 25: 439-445.

35) Martin JY, Schwartz Z, Hummert TW, Schraub DM, Simpson J, Lankford Jr J, Dean DD, Cochran DL, Boyan BD. Effect of titanium surface roughness on proliferation, differentiation, and protein synthesis of human osteoblastic-like cells (MG63). J Biomed Mater Res 1995; 29: 389-401.

36) Morgan J, Holtman KR, Keller JC, Stanford CM. In vitro mineralization and implant calcium phosphate- 
hydroxyapatite crystallinity. Implant Dent 1996; 6: 264271.

37) Maxian SH, Di Stefano T, Melican MC, Tiku ML, Zawadsky JP. Bone cell behavior on Matrigel-coated $\mathrm{Ca} / \mathrm{P}$ coatings of varying crystallinities. J Biomed Mater Res 1998; 40: 171-179.

38) Ban S, Arimoto N, Harada A, Hasegawa J, Maruno S. Bioactivity of hydrothermal-electrochemically deposited apatite in vitro and in vivo. Key Engin Mater 2001; 192-195: 159-162.

39) Allard RHB, Swart JGN. Orbital roof reconstruction with a hydroxyapatite implant. J Oral Maxillofac Surg 1982; 40: 237-239.
40) Holy CE, Dang SM, Davies JE, Shoichet MS. In vitro degradation of a novel poly (lactide-co-glycolide) $75 / 25$ foam. Biomaterials 1999; 20: 1177-1185.

41) Andriano KP, Tabata $Y$, Ikada $Y$, Heller J. In vitro and in vivo comparison of bulk and surface hydrolysis in absorbable polymer scaffolds for tissue engineering. J Biomed Mater Res 1999; 48: 602-612.

42) Watanabe $\mathrm{T}$, Ban S, Itoh $\mathrm{T}$, Tsuruta S, Kawai T, Nakamura H. Biocompatibility of composite membrane of oriented needle-like apatite and biodegradable copolymer with soft and hard tissues in rats. Dent Mater J 2004; 23: 609-612. 